
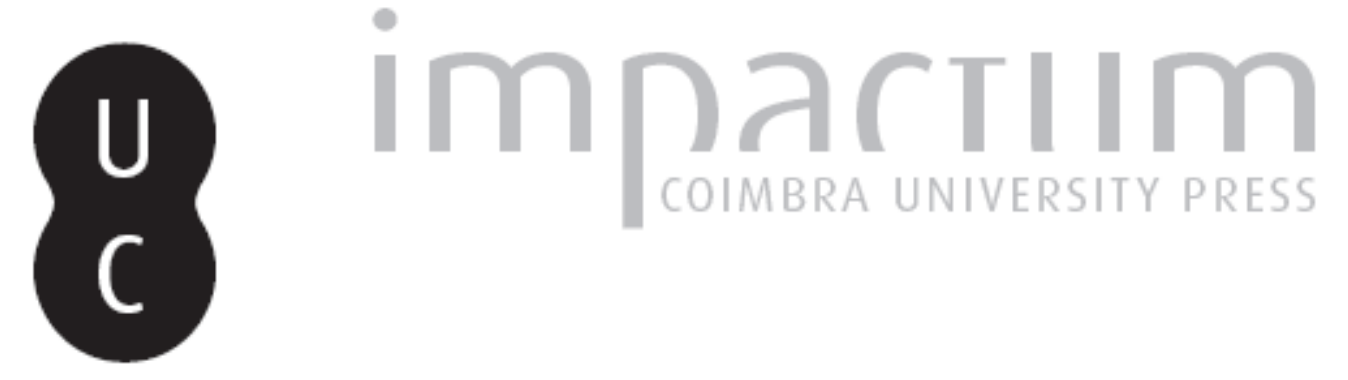

\title{
Portugal e as Conferências Sanitárias Internacionais (em torno das epidemias oitocentistas de cholera-morbus)
}

Autor(es): $\quad$ Garnel, Maria Rita Lino

Publicado por: Centro de História da Sociedade e da Cultura

URL persistente:

URI:http://hdl.handle.net/10316.2/39584

DOI:

DOI:http://dx.doi.org/10.14195/1645-2259_9_9

Accessed : $\quad$ 26-Apr-2023 15:42:16

A navegação consulta e descarregamento dos títulos inseridos nas Bibliotecas Digitais UC Digitalis, UC Pombalina e UC Impactum, pressupõem a aceitação plena e sem reservas dos Termos e Condições de Uso destas Bibliotecas Digitais, disponíveis em https://digitalis.uc.pt/pt-pt/termos.

Conforme exposto nos referidos Termos e Condições de Uso, o descarregamento de títulos de acesso restrito requer uma licença válida de autorização devendo o utilizador aceder ao(s) documento(s) a partir de um endereço de IP da instituição detentora da supramencionada licença.

Ao utilizador é apenas permitido o descarregamento para uso pessoal, pelo que o emprego do(s) título(s) descarregado(s) para outro fim, designadamente comercial, carece de autorização do respetivo autor ou editor da obra.

Na medida em que todas as obras da UC Digitalis se encontram protegidas pelo Código do Direito de Autor e Direitos Conexos e demais legislação aplicável, toda a cópia, parcial ou total, deste documento, nos casos em que é legalmente admitida, deverá conter ou fazer-se acompanhar por este aviso.

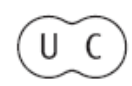



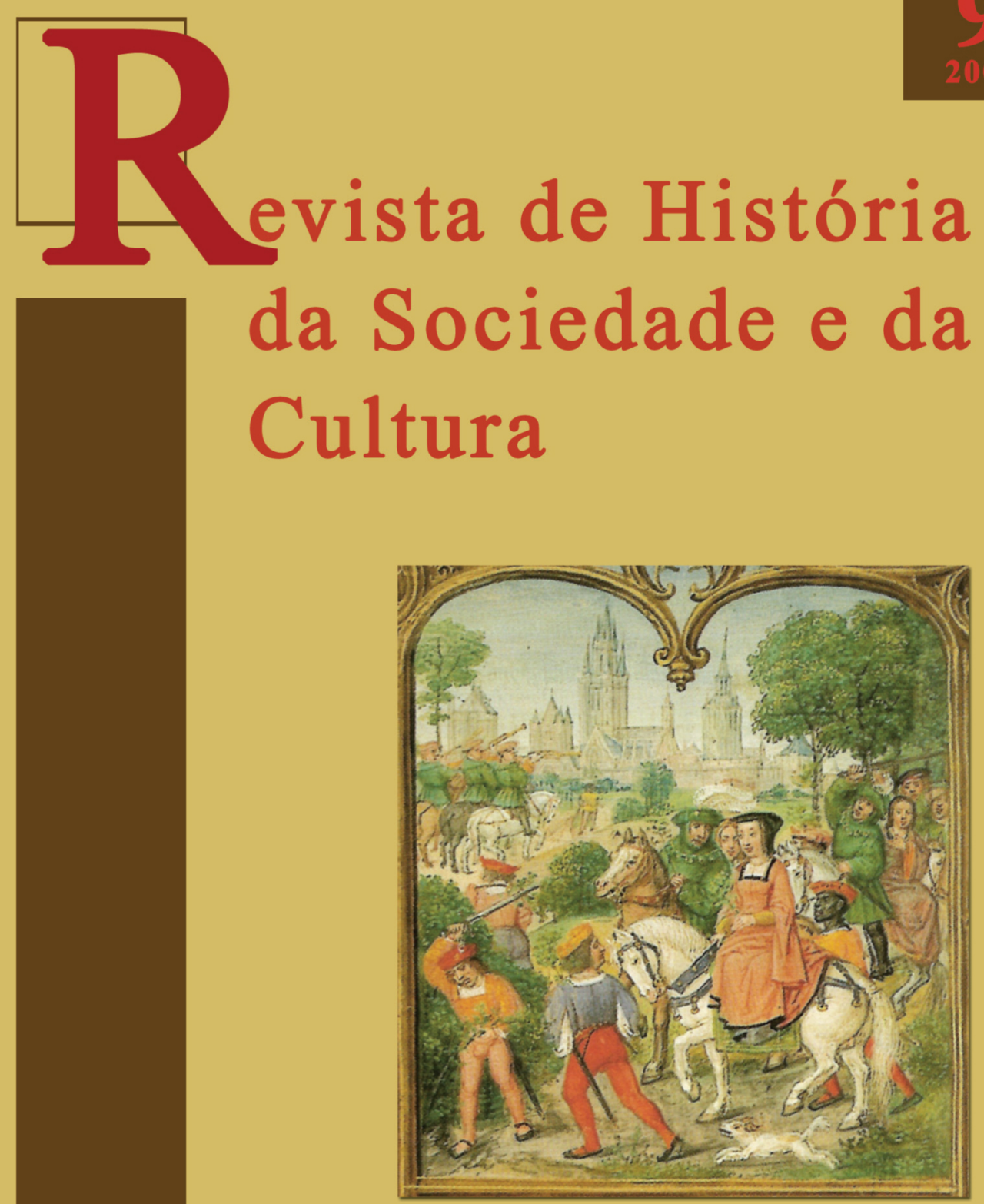

Centro de História da Sociedade e da Cultura Universidade de Coimbra

Coimbra 


\title{
Portugal e as Conferências Sanitárias Internacionais (Em torno das epidemias oitocentistas de cholera-morbus)
}

\author{
Maria Rita Lino Garnel \\ CesNova (Centro de Estudos de Sociologia da Universidade Nova de Lisboa) \\ e bolseira de pós-doutoramento da FCT \\ rgarnel@netcabo.pt
}

Texto entregue em/Text submited on: 10/05/2009

\section{Resumo/Abstract:}

Entre as epidemias que, no século XIX, afectaram as populações europeias a cólera foi das que maior susto provocou, perante a impotência do saber médico e dos Estados. As medidas públicas tomadas no combate antiepidémico divergiam de país para país. O impacto económico destas divergências tornou-se uma preocupação e, a partir de 1851, as potências europeias reuniram-se regularmente em Conferências Sanitárias Internacionais que visavam a discussão científica da nosologia e a uniformização das medidas que, sem pôr em risco as populações, minimizassem as demoras que sujeitavam o comércio internacional. Os debates dão conta de um conhecimento científico em mutação, e ilustram posições nacionais divergentes e mutáveis. O objectivo deste artigo não é seguir detalhadamente as epidemias de cólera, nem fazer o levantamento exaustivo do estado do conhecimento médico e dos diferentes tratamentos prescritos ao longo de Oitocentos em Portugal. As questões que se levantam são as seguintes: 1) qual a posição adoptada por Portugal nas Conferências Sanitárias Internacionais, perante as epidemias de cólera?; 2) como se justificaram, interna e diplomaticamente, as políticas adoptadas?; 3) que modelo e exemplos se seguiram no combate à epidemia?

Among the 19th century epidemics that afflicted the European populations, cholera was the one that caused the most panic, in light of the lack of medical know-how and the incapacity of the States. Different countries adopted distinct measures to fight the epidemic. The economic impact of such divergence became a concern and from 1851 the European powers began meeting on a regular basis under International Health Conferences to discuss the nosology and standardisation of measures which would minimise the delays of international trade, without endangering the lives of the people. These debates denote changes in the scientific knowledge, and illustrate divergent and mutating national positions. The paper's purpose is not to monitor in detail the cholera epidemics, nor to carry out in depth analyses of the status quo of medical know how and different treatments prescribed in Portugal in the eighteen-hundreds. The following are the core issues raised: 1) Which position did Portugal adopt at the International Health Conferences in relation to the cholera epidemics?; 2) How were the policies adopted justified domestically and diplomatically?; 3) Which model and examples were followed in combating the epidemic?

Palavras chave/Key words:

Cólera; Portugal; Conferências Sanitárias Internacionais.

Cholera; Portugal; International Health Conferences. 


\section{Introdução}

Em 1832 a Europa foi assolada pela primeira pandemia de cólera. A doença não era desconhecida, sobretudo dos países colonizadores do Oriente, onde grassava endemicamente. A intensificação das trocas comerciais acabou por potenciar a sua irradiação para fora do foco indiano original; na década de 1820, ela afligiu a Rússia e, dez anos depois, os países mais ocidentais. Ao longo do século XIX, e em intervalos decenais quase regulares, seis epidemias apavoraram as populações europeias, perante a impotência da medicina e dos Estados ${ }^{1}$.

As epidemias não eram novidade para os países europeus, desde há muito e periodicamente confrontados com várias pestilências: peste bubónica, varíola, lepra, febre-amarela. Mas a cólera era nova, atacava com ferocidade e propagava-se velozmente, desafiando as medidas preventivas costumeiras. As terapêuticas e profilaxias pareciam inúteis. Cordões sanitários, quarentenas, queima de ervas aromáticas pelas ruas, sangrias, abafos, banhos de vapor e tiras de flanela enroladas em torno do abdómen não surtiam efeito. O saber médico parecia impotente perante tal calamidade.

Em 2005, Peter Baldwin num estudo comparativo levantava as seguintes questões: dado que o conhecimento médico era sensivelmente o mesmo em toda a Europa por que adoptaram os diferentes Estados nacionais medidas antiepidémicas tão divergentes? Por que é que, perante a ameaça de cólera, uns defenderam medidas que restringiam os movimentos de pessoas e bens e outros insistiram na higienização das cidades? ${ }^{2}$

O impacto económico destas divergências nacionais tornou-se notório a partir de meados da centúria. Por um lado, os transportes terrestres e marítimos encontravam em cada fronteira um emaranhado de exigências diferenciadas, que embaraçavam o trânsito comercial; por outro, a má saúde dos grupos laboriosos e uma elevada mortalidade tinham custos consideráveis ${ }^{3}$. Daí que,

1 KOLATA, Gina - Flu. The story of the great influenza pandemic of 1918 and the search for the virus that caused it. New York: Touchstone, 2005, p. 41-47.

2 BALDWIN, Peter - Contagion and the State in Europe,1830-1930. Cambridge: Cambridge University Press, 2005.

3 LATOUR, Bruno - The Pasteurization of France. Cambridge; Massachussets; London: Harvard University Press, 1993, p.18. 
a partir de 1851, as potências europeias se tenham reunido regularmente em Conferências Sanitárias Internacionais que visavam não só a discussão científica da nosologia, como também apostavam na uniformização das medidas que, sem pôr em risco as populações, minimizassem as demoras e os incómodos a que sujeitavam o comércio internacional. Os debates que tiveram lugar nas diferentes Conferências - e nas quais Portugal foi presença assídua - dão conta de um conhecimento científico em constante mutação, e ilustram posições nacionais divergentes e mutáveis ao longo do tempo. As grandes potências europeias - Inglaterra, França e mais tarde a Alemanhaposicionaram-se em campos por vezes antagónicos, pressionando os países mais pequenos e periféricos a prescindirem da severidade das medidas quarentenárias.

O objectivo deste artigo não é seguir detalhadamente as epidemias de cólera, nem fazer o levantamento exaustivo do estado do conhecimento médico e dos diferentes tratamentos prescritos ao longo de Oitocentos em Portugal. As questões que aqui se levantam são devedoras das enunciadas por Baldwin; trata-se de tentar perceber: 1) qual foi a posição adoptada por Portugal, nas Conferências Sanitárias Internacionais, perante as epidemias de cólera? 2) como se justificaram - interna e diplomaticamente - as políticas adoptadas? 3) que modelo e que exemplos se seguiram no combate à epidemia?

Estas questões pressupõem a existência de uma organização de saúde pública. Em Portugal e no dealbar do século XIX, tal estrutura administrativa era incipiente.

Não quer isto dizer que não houvesse já algumas estruturas de socorro e amparo na doença. Não se ignora a existência de iniciativas, privadas, ou o trabalho das Misericórdias e das instituições religiosas. O que, todavia, sustentamos é que só no século XIX e, sobretudo, com o estabilização da Monarquia Constitucional (1834), o poder central começou a chamar a si, muito gradualmente, a responsabilidade da saúde pública. Assegurar a saúde dos portugueses de modo a que a mão-de-obra fosse útil e produtiva (e também dócil), afigurava-se um projecto de longo prazo, e que exigia o difícil equilíbrio entre direitos e liberdades individuais e o bem público. Porque se por um lado o regime político gostava de se pensar liberal, 
por outro, o Estado estava obrigado a garantir os Socorros Públicos (Carta Constitucional, artigo $\left.145 .^{\circ} \S 29 .^{\circ}\right)$ e, constitucionalmente podia determinar a dispensa das formalidades que garantiam a liberdade individual nos casos em que a Pátria corresse perigo iminente (artigo $145 .^{\circ} \S 34 .^{\circ}$ ). Claramente, as epidemias ameaçavam a Pátria de devastação populacional.

Em síntese, e olhando o panorama internacional, poder-se-iam apontar dois tipos extremos de posição: os países que, no combate às doenças contagiosas e sobretudo em relação à cólera, perfilharam políticas de quarentena de pessoas e bens; e aqueles que, na mesma luta, optaram por centrar os esforços no saneamento das cidades e habitações. Baldwin relembra, a propósito, a teoria formulada, em 1948, por Erwin Ackercknecht, tão atractiva quanto simplificadora ${ }^{4}$ : as políticas de quarentena, cordões sanitários e lazaretos teriam sido característica dos regimes autocráticos e conservadores, enquanto os governos de pendor mais liberal e progressista teriam preferido políticas higienistas.

Na verdade, as coisas não foram tão simples: em país nenhum a política antiepidémica seguiu rigidamente um modelo; ao invés, todos procuraram consoante as circunstâncias - a gravidade da epidemia, a posição geográfica na marcha de progressão epidémica, o estado da opinião pública e da economia, as possibilidades financeiras, as estruturas administrativas e a opção dos seus vizinhos territoriais e dos parceiros comerciais - acasalar medidas que impunham limites à circulação de pessoas e bens, com outras que visavam transformar a cidade e as condições e hábitos de vida dos seus habitantes (que resta provar não terem sido atentatórias dos direitos e liberdades individuais). E a opção política, variável no espaço e no tempo, esteve sempre condicionada pelo saber médico, ele próprio variável no tempo, e pela força ou fraqueza das elites médicas nacionais, que muitas vezes ajudaram a recobrir com o manto da ciência legitimadora as políticas adoptadas.

4 ACKERCKNECHT, Erwin - Anticontagionism between 1821 and 1867. Bulletin of the History of Medicine. 22, 5 (September-October 1948), citado por BALDWIN, Peter Contagion and the State..., cit., p.12. 


\section{As teorias explicativas das doenças: 0 caso da cólera}

Ao começar o século XIX, a ciência médica europeia questionava as teorias do contágio. Sabia-se que certas doenças se propagavam, por vezes com efeitos catastróficos, ainda que não fosse claro o modo da sua transmissão. E dada a velha teoria dos humores, explicava-se o padecimento por uma predisposição pessoal alterada. Mas, desde finais de Setecentos, as modernas teorias médicas começaram a entender a doença como uma invasão do corpo e entraram a duvidar que ela fosse resultado dos desequilíbrios individuais.

Numa revivescência do pensamento hipocrático, os médicos insistiam, agora, na importância das condições climatéricas e/ou telúricas, no que veio a ser conhecido como a teoria miasmática. A teoria, cujas raízes mergulhavam na cultura clássica, entendia que algumas epidemias eram fruto da má qualidade do ar. Esta deterioração qualitativa, era causada pela putrefacção de matérias orgânicas ou pelos fumos poluentes das indústrias, numa acumulação de efeitos nocivos que os ventos se encarregavam de disseminar, mas também, com o tempo, de rarefazer. Compreendia-se assim o alastramento de epidemias. Percebe-se como esta argumentação miasmática parecia explicar a simultaneidade dos casos epidémicos e como ela se casava bem com o olhar reprovador que as elites lançavam sobre os grupos mais desfavorecidos da população. A imundície das habitações, os despejos nas ruas, o pouco uso da água que faziam, era o conjunto de factores responsável pelas doenças. E a esta sujidade somavam-se, ainda, a ignorância, o alcoolismo, as condutas prevaricadoras e a imoralidade do comportamento sexual, males que também eles eram, à sua maneira, contagiosos (e hereditários) $)^{5}$. Pelo que importava transformar o meio, conter os miasmas, reformar os comportamentos e quebrar as cadeias da hereditariedade malsã.

Este novo saber miasmático não destronou de imediato a crença no contágio nem os seus corolários práticos (quarentenas e cordões sanitários). As duas teorias coexistirão durante todo o século.

5 HAMLIN, Christopher - Public health and social justice in the age of Chadwick. Britain, 1800-1854. Cambridge: Cambridge University Press, 1998, p. 23. 
Nos inícios da década de 1830 tornava-se claro que os países mais ocidentais da Europa seriam invadidos pela epidemia de cólera. Em Portugal, e já com a notícia de que a moléstia invadira Londres e Paris ${ }^{6}$, a Impressão Régia dava à estampa várias obras sobre a doença. Os autores portugueses estavam a par do que se ia publicando em outras capitais ${ }^{7}$. Expunham-se os sintomas, e considerava-se a ansiedade como condição agravante: "quanto menor o susto menor o risco"; desdramatizava-se a epidemia pelo "pequeno risco que apresenta a comunicação do Cholera". Não é que se negasse a gravidade da doença, mas entendia-se que "se há desenvolvido demasiado terror (...) desproporcionado, incompetente e prematuro"».

Não se negava o contágio, que parecia depender das predisposições individuais, admitindo-se também que "os tecidos de algodão e lã, as peles, pelissas e penas" eram materiais capazes de transmitir a doença. Daí que ambos, pessoas e bens, devessem ser sujeitos a quarentena, quando não impedidos de entrar no País. Como Rodríguez Ocaña sublinha, e para o território espanhol, a palavra «resguardo» tanto teve um significado médico - o resguardo da saúde -, como significou o policiamento fronteiriço: ou dito de outra maneira, as atenções da saúde pública implicaram sobretudo uma estrita definição defensiva das tarefas sanitárias e uma atenção vigilante aos males que vinham de fora' ${ }^{9}$.

Mais do que o risco de permitir a entrada a pessoas doentes ou a artigos potencialmente infectados, entendia-se que o verdadeiro perigo era de outra ordem; o ar seria a causa principal de disseminação infecciosa, a que se juntava "a pouca limpeza dos lugares públicos, sobretudo quando a

6 PINTO, Agostinho Albano da Silveira - Noções sobre a cholera-morbus indiana extrahidas principalmente da obra de James Kennedy e d'outros. Lisboa: Impressão Regia, 1832, p. IV.

7 Veja-se também o título seguinte: Instrucção popular acerca da enfermidade chamada cholera-morbus ou úteis providencias contra essa moléstia publicadas pela commissão central de saúde publica de Paris creada pelo governo e composta pelos senhores Pariset, Esquirol, etc.. Lisboa: Impressão Regia, 1832.

8 PINTO, Agostinho Albano da Silveira - Noções..., cit., p. III-IV.

9 RODRÍGUEZ OCAÑA, Esteban - Salud Pública en España. Ciência, profesión y política, siglos XVIII-XX. Granada: Universidad de Granada, 2005, p.17-18. 
população é pouco abastada e já deteriorada pela pobreza e miséria"10; devia-se, portanto, evitar a "respiração numa atmosfera impregnada de miasmas ou vapores dos doentes, e mesmo exalações dos corpos animais ou vegetais em decomposição" ". Como se vê, em Portugal, tal como nos outros países europeus, admitiam-se como causas principais da epidemia os factores ambientais. Daí que se apelasse às autoridades para que redobrassem os cuidados, sobretudo "nas grandes cidades e vilas populosas (...) que as ruas estejam limpas de imundícies (...) a fim de evitar as emanações e exalações fétidas, as quais corrompem o ar que continuamente respiramos que deve assim viciado alterar a nossa constituição física e dispor com mais facilidade a contrair a epidemia" ${ }^{12}$. Também se recomendava evitar os ajuntamentos "nos espectáculos e Assembleias", o respirar junto de "águas estagnadas"13, os "abusos dos prazeres de Vénus, o medo, a tristeza, a indigência e crápula" ${ }^{14}$. Conhecendo bem os limites da capacidade de actuação das autoridades - sobretudo na conjuntura de guerra civil que o país atravessava-, apelava-se à cooperação de todos, "porque a experiência tem provado mais de uma vez que a desordem, o tumulto e a insubordinação e a indocilidade aumentam os perigos de epidemia (...). Portanto recomenda-se ao Povo que observe com exactidão as regras de polícia sanitária" ${ }^{15}$. Benevides propõe mesmo um plano de combate antiepidémico, com Juntas de Saúde em cada freguesia, comissões de socorro formadas pelos irmãos das confrarias do Santíssimo Sacramento, e uma vigilância apertada do estado de limpeza das ruas da paróquia. Se a melhor prevenção consistia em evitar o "uso das causas", o mesmo autor não hesita em considerar que o isolamento "é um dos melhores preservativos" e que quarentenas e lazaretos são as melhores armas de que se pode dispor. Pragmaticamente, e embora reconhecesse

${ }^{10}$ BENEVIDES, Ignacio António da Fonseca - Manual de Instrucções preservativas e curativas da Cholera-Morbus epidémica, espasmódica, asiática, pestilencial, etc. Lisboa: Impressão Regia, 1832, p.10.

${ }^{11}$ Memoria sobre a cholera-morbus epidémica offerecida à Real Escola de cirurgia do Porto por hu seu antigo alumno em testemunho de gratidão. Lisboa: Impressão Regia, 1832, p. 5.

12 BENEVIDES, Ignacio António da Fonseca - Manual..., cit., p. 11.

${ }^{13}$ PINTO, Agostinho Albano - Noções..., cit., p.VII.

${ }^{14}$ Memoria sobre a cholera-morbus..., cit., p.5.

${ }^{15}$ BENEVIDES, Ignacio António da Fonseca - Manual..., cit., p. 28. 
a "dificuldade de provar a natureza contagiosa desta doença", na dúvida aconselhava "a prudência e o bem da humanidade em higiene pública, que a declaração se faça (...) pela realidade do contágio" ${ }^{16}$.

A partir destas obras, percebem-se as linhas gerais de actuação das autoridades sanitárias ao longo do século XIX. As elites médicas, não negando o poder contagioso deste mal que vinha de fora, acentuavam a necessidade de actuar a outro nível, providenciando o saneamento das cidades, o abastecimento abundante de boas águas e disciplinando os comportamentos das classes laboriosas, a quem se exigia em nome da saúde (individual e social) a correcção dos excessos. Em suma, os cuidados com a saúde individual eram assunto que ultrapassava a esfera privada.

A cólera atingirá Portugal, em 1832, "trazida a bordo de um navio que, de Ostende, transportava soldados para ajudarem D. Pedro no cerco do Porto" ${ }^{17}$. Aí grassará com terrível intensidade e, passados poucos meses, declarava-se em Lisboa, onde terão morrido cerca de treze mil habitantes.

Nas décadas de 1840 e 1850 os debates sobre a contagiosidade da cólera continuarão. Simultânea e sintomaticamente, multiplicaram-se as obras mais genericamente dedicadas à Higiene Pública, cujo ensino se fazia nas Escolas Médico-Cirúrgicas de Lisboa e Porto e na Faculdade de Medicina de Coimbra (ainda que em acumulação com outras disciplinas). Tal como em outros países europeus, a higiene era assunto lato que compreendia o saneamento da cidade, a qualidade das águas e da alimentação, a limpeza das habitações, do vestuário e dos corpos e o comportamento moral. O sucesso das teorias miasmáticas explica-se, também, por uma confluência de argumentos: o peso da tradição, a crescente sensibilidade olfactiva ${ }^{18}$, os preconceitos sociais. Em 1854, contudo, uma nova epidemia de cólera manifestou-se com violência (a que se seguirá uma de febre amarela). A mesma pestilência voltará no ano de 1865. As obras publicadas ao longo das décadas de 1840, 1850 e 1860 continuavam a insistir no mesmo

${ }^{16}$ PINTO, Agostinho Albano da Silveira - Noções..., cit., p. 42.

${ }^{17}$ CORREIA, Fernando da Silva - Portugal Sanitário (Subsídios para o seu estudo. Lisboa: Ministério do Interior ; Direcção Geral de Saúde, 1938, p. 465.

${ }^{18}$ CORBIN, Alain - Histoire et anthropologie sensorielle - Le Temps, le désir et l'horreur. Essais sur le XIXe siècle. Paris : Champs/Flammarion, 1991, p. 229 e também VIGARELLO, Georges - Histoire des pratiques de santé. Le sain et le malsain depuis le Moyen Âge. Paris: Éditions du Seuil, 1999. 
tipo de conselhos e a medicina parecia não ter soluções para a moléstia ${ }^{19}$. O depauperamento da população era comummente atribuído aos maus hábitos higiénicos e às condutas excessivas e prevaricadoras que o Estado tardava em disciplinar. A partir da década de 1850, começa-se a insistir na predisposição degenerescente dos grupos mais desfavorecidos. Em Portugal, contudo, continuou a apostar-se em medidas restritivas e esporádicas, quando havia a ameaça ou se declarava uma epidemia, evitando-se o crescimento de despesas permanentes em matéria de administração sanitária.

Com a revolução pasteuriana, a partir de meados da década de 1880, e sobretudo com a descoberta do vibrião da cólera por Koch (1883), esclareceram-se muitas questões, designadamente o agente da cólera, e os seus modos de propagação e contágio. Ainda que as elites médicas portuguesas tenham estado sempre atentas aos avanços da nascente bacteriologia, as medidas tomadas na profilaxia da moléstia indiana só começaram a mudar nos inícios do século XX. As autoridades e as populações pareciam confiar mais em quarentenas, cordões sanitários, lazaretos e desinfecções de mercadorias.

Foi o que se passou, por exemplo, com a epidemia de cólera que se declarou em Espanha, no ano de 1884, e que ali grassou com intensidade durante dois anos. Em Portugal organizou-se a defesa sanitária nos moldes mais tradicionais: com os conselhos e elogios de médicos como Lourenço d'Almeida Azevedo, lente catedrático da Faculdade de Medicina, defensor do carácter não contagioso da cólera e que fora médico no Hospital de coléricos de Coimbra, em $1856^{20}$, o governo ordenou o cordão sanitário do país, que foi mantido pelo exército durante os dois anos de ameaça; exigiram-se passaportes sanitários e improvisaram-se lazaretos junto das fronteiras com Espanha (em Marvão, Elvas, Vilar Formoso, Valença e Vila Real) e postos de vigilância nos entroncamentos das linhas-férreas ${ }^{21}$. Tudo isto com os protestos de vozes autorizadas como Miguel Bombarda ou

${ }^{19}$ Veja-se, a título de exemplo, VIANA, Francisco José da Cunha e BARBOSA, António Maria - Ensaio sobre a cholera epidémica. Lisboa: Livraria de J. P. M. Lavado, 1854.

${ }^{20}$ AZEVEDO, Lourenço d'Almeida - A Cholera-morbus. Sua Profilaxia e tratamento. Coimbra: Imprensa da Universidade, 1884, p. 10-11.

${ }^{21}$ BELÉM, A. M. Cunha e ENNES, Guilherme José - Os Lazaretos terrestres de fronteira nos annos de 1884 e 1885. Relatório a Sua Excelência o Ministro do Reino. Lisboa: Imprensa Nacional, 1886. 
o jovem Ricardo Jorge, na circunstância, e por razões puramente científicas, aliados insuspeitos dos interesses do comércio internacional ${ }^{22}$. Desenhava-se, com maior nitidez, uma clivagem entre o saber técnico e a opinião pública, a qual, intuitiva e prontamente, confiava mais nos dispositivos tradicionais de protecção $0^{23}$.

\section{As Conferências Sanitárias Internacionais}

A explosão de Congressos que se seguirá ao Tratado de Viena (1815) teve objectivos múltiplos: a cooperação europeia para a paz, a discussão de interesses comuns, a afirmação das novas entidades políticas e a confirmação das potências europeias, mas também o aprofundamento e alargamento do conhecimento. Entre 1835 e 1850 reuniram-se cerca de vinte Congressos para tratar dos mais variados temas: político-diplomáticos, literários, científicos ${ }^{24}$. Estes inauguravam uma nova modalidade de intercâmbio científico, até aí confinado às Academias e Sociedades científicas, à troca epistolar entre os seus membros e à circulação de publicações. Mas é verdadeiramente a partir da década de 1850 , que se acelera esta nova forma de circulação internacional do saber que deixa de ficar confinado a uma elite e transborda para o espaço público, que ajuda a construir.

Veja-se, então, qual foi a posição adoptada por Portugal nas Conferências Sanitárias Internacionais.

A primeira reuniu-se em Paris, em 1851, e, tal como as que se seguiram, visava a simplificação dos regulamentos marítimos nos portos mediterrânicos. Portugal foi representado pelo secretário da Legação de Paris, João Mouzinho da Silveira, e pelo Dr. José Maria Grande ${ }^{25}$.

${ }^{22}$ A Medicina Contemporânea. Hebdomadario Portuguez de Sciencias Medicas. IV Anno, nº12, 21-III-1886, p. 97.

${ }^{23}$ BOURDELAIS, Patrice - Les Logiques du dévéloppement de l'hygiène publique - Les Hygiènistes. Enjeux, modèles et pratiques (XVIIlème-XXème siècles). Paris: Éditions Bélin, 2001, p. 17.

${ }^{24}$ BRIAN, Eric - Transactions statistiques au XIX ème siècle. Mouvements internationaux de capitaux symboliques in Actes de la recherche en sciences sociales, 2002/5, p. 36.

${ }^{25}$ José Maria Grande (1799-1857), bacharel em Medicina pela Universidade de Coimbra e doutor em Medicina pela Universidade de Lovaina. Par do Reino, médico visitador dos 
O sistema internacional baseava-se nas cartas de saúde apresentadas pelos navios; estas atestavam não só a saúde a bordo de tripulantes e passageiros, mas tinham também em conta o estado epidemiológico dos portos de proveniência e o tipo de carga transportada. Deste modo, a classificação das cartas de saúde podiam variar entre cartas limpas, duvidosas, suspeitas, sujas ou agravadas. Ao longo do percurso marítimo, e em cada porto, as autoridades de saúde locais e os representantes consulares do porto de destino deviam certificar o estado higiénico do navio e avaliar a potencial perigosidade da carga.

A classificação dos navios pelas cartas de saúde implicava diferentes tempos de quarentena e, consoante a pestilência declarada ou suspeita, obrigava a demoras que podiam ir de oito a quarenta dias de isolamento. Também a inspecção e/ou desinfecção das mercadorias variava quanto à moléstia e ao tipo de carga, por vezes danificando-a irremediavelmente, e podia mesmo ser ordenada a sua destruição.

A Conferência não teve um grande sucesso dadas as enormes disparidades das medidas administrativas nacionais. Contudo, estava lançado o mote para as que se lhe seguiram e, nesta ocasião, Portugal foi um dos poucos países que não hesitou em aderir à Convenção, ainda que na prática isso não se tivesse reflectido em nenhuma medida legislativa ou regulamentar.

Talvez tenha sido a epidemia de cólera, que grassou em toda a Europa, em 1864 e 1865, ou os receios de próxima abertura do Canal de Suez - o primeiro navio atravessá-lo-á em Fevereiro de 1867, ainda que a inauguração oficial só se tenha realizado em 1869 - o facto é que a Turquia, com o apoio da França, Rússia e Inglaterra, apelará, em 1865, à realização de uma nova Conferência Sanitária Internacional. Esta realizar-se-á em Constantinopla, entre 13 de Fevereiro de 1866 e 26 de Setembro do mesmo ano.

hospitais militares do Alentejo e professor de botânica da Escola Politécnica de Lisboa. DIAS, António Carvalho - A Conferência Sanitária Internacional de 1851 e o regime quarentenário português. separata do Boletim do Instituto Superior de Higiene Doutor Ricardo Jorge. (1953) 38 . 


\subsection{As Conferências de Constantinopla (1866) e Viena (1874)}

Portugal que, habitualmente, era representado naquela cidade pelo enviado diplomático italiano (Conde de Greppi), esteve presente com dois delegados: o encarregado de negócios Eduardo Pinto de Soveral e o médico Bernardino António Gomes (filho). O governo português anuía aos desejos da Sublime Porta que não quereria ver na Conferência os diplomatas acreditados em Constantinopla. Tanto quanto possível o quotidiano diplomático não devia ser perturbado e a isenção científica não seria prejudicada por interesses estabelecidos. Soveral asseguraria as conversações diplomáticas e políticas, enquanto Bernardino António Gomes, autor de um trabalho sobre pestilências, que aproveitará para reimprimir em Constantinopla ${ }^{26}$, participaria nas discussões médicas, que deveriam influenciar os acordos diplomáticos. Contudo e logo no início dos trabalhos, torna-se claro que será justamente o contrário que acontecerá: as indicações ou conclusões médicas serão condicionadas pelos interesses políticos (e comerciais) na região ${ }^{27}$. As propostas francesas encontrarão, ao longo da conferência, o antagonismo explícito ou implícito da Inglaterra, com a Rússia a alinhar com as primeiras, e a Turquia a fomentar o equilíbrio antagónico entre as três grandes potências. Esta é a leitura informada do delegado diplomático português.

Perante os receios de uma nova invasão de cólera, potenciada pela grande peregrinação anual a Meca - responsabilizada pela invasão colérica da Europa pelo menos por duas vezes ${ }^{28}$-, a França propunha que se interrompessem as navegações, no caso do aparecimento da epidemia "obrigando as caravanas a voltar pelo deserto" 29 . Gomes, por seu lado, dá conta da mesma intenção

${ }^{26}$ GOMES, Bernardino António - Aperçu historique sur les épidémies de choléra-morbus et de fièvre jaune en Portugal, dans les années de 1833-1865. Constantinople: Imprimerie Centrale, 1866.

${ }^{27}$ Arquivo Histórico e Diplomático - Ministério dos Negócios Estrangeiros (Lisboa) (de agora em diante AHD-MNE) - Conferências Sanitárias, Constantinopla, M 194 (Eduardo Pinto de Soveral, ofício manuscrito de 21 de Fevereiro de 1866),

${ }^{28}$ Rapport sur les questions du programme relatives à l'origine, a l'endémicité, a la transmissibilité et a la propagation du choléra, Annexe au Procés-verbal $n^{\circ} 9$ de la Conférence Sanitaire. Constantinople: Imprimerie Centrale, 1866, p. 75.

${ }^{29}$ AHD-MNE - Conferências Sanitárias, Constantinopla, M 194 (Eduardo Pinto de. Soveral, ofício manuscrito de 13 de Fevereiro de 1866). 
francesa. A crescente rapidez das comunicações marítimas era factor de risco acrescido na propagação da moléstia, enquanto que, a travessia do deserto consistiria numa espécie de quarentena natural ${ }^{30}$.

Os ingleses interessados em combater a influência francesa na região, sobretudo na zona do Suez, não queriam prejudicar o tráfego das suas embarcações. Escudado pelas reformas sanitárias levadas a cabo no seu próprio país, sob a autoridade sapiente de Chadwick, e com o acordo do saber alemão, sob a orientação de Pettenkofer, o delegado inglês Goodeve não tinha reservas quanto ao princípio de que "l'air ambiant est le véhicule principal de l'agent générateur du choléra" e abstinha-se de concluir - como fazia o resto da comissão técnica - que "la transmission de la maladie par l'atmosphère reste (...) limitée a une distance très rapprochée du foyer d'émission" 31 . O higienismo inglês, tenaz defensor da teoria miasmática no que à cólera dizia respeito, casava muito bem com os interesses comerciais britânicos.

A maioria dos médicos - representantes da França, Turquia, Itália, Portugal e outros - não estavam contudo tão certos. O relatório final que temos vindo a citar concluía: que a cólera era uma moléstia de importação asiática; que era contagiosa e que “jamais une épidémie s'est propagée d'un point à autre dans un temps plus court que celui nécéssaire à l'homme pour s'y transporter"32; que a água e certos alimentos podiam ser as vias de entrada no organismo do agente patogénico, ainda que se admitisse que eram as vias respiratórias o principal meio pelo qual o agente tóxico penetrava no corpo humano; e, aceitando que o período de incubação pudesse não ultrapassar alguns dias (ainda que não se especificasse o número), os clínicos não hesitavam em considerar o trânsito marítimo como o meio mais favorável à expansão epidémica e em considerar as grandes aglomerações urbanas e as concentrações populacionais esporádicas - navios, exércitos, feiras e peregrinações - factores da propagação da pestilência. Finalmente, concluíram pelo perigo de contágio oferecido pelas mercadorias provenientes de origem empestada e recomendavam especial cuidado com os objectos

${ }^{30}$ AHD-MNE - Conferências Sanitárias, Constantinopla, M 194 (Bernardino António Gomes, ofício manuscrito de 13 de Fevereiro de 1866).

${ }^{31}$ Rapport sur les questions du programme... cit., p. 90.

${ }^{32}$ Idem, p. 36. 
e roupas de uso dos doentes coléricos. Sem surpresas, o delegado inglês absteve-se de votar tais conclusões.

Todos os representantes estiveram de acordo em recomendar: a melhoria do saneamento de portos, cidades e navios; o reforço de uma polícia sanitária; as visitas preventivas, os socorros aos doentes, a publicação de instruções populares e as campanhas de desinfecção ${ }^{33}$. Menos populares foram as recomendações que visavam estabelecer postos de controlo sanitário no Mar Vermelho. Neste ponto os delegados britânicos (Goodeve e Dickson) foram muito claros na recusa.

A Conferência Sanitária de Constantinopla foi palco das divergências científicas e políticas europeias no que tocava à cólera. Mas, também resultou claro que pesando os inconvenientes causados ao comércio internacional pelas medidas restritivas e os prejuízos económicos causados pela mortalidade, a maioria dos médicos presentes não hesitaram em se pronunciar pela manutenção de medidas quarentenárias - ainda que todos fossem mais ou menos concordes com Bernardino António Gomes acerca da pouca eficácia dos cordões sanitários ${ }^{34}-$, e insistiram na importância de se reforçarem as restrições junto do seu foco original - a Índia ${ }^{35}$. A Inglaterra, contudo, inicia em Constantinopla um caminho mais liberalizador. A sua posição geográfica, o tempo de viagem até aos portos ingleses, o estado do saber higienista britânico e a sua estrutura de administração sanitária permitia-lhe defender essa posição.

Os representantes portugueses votaram sempre com a maioria, nunca se abstendo nem votando contra. Sem dúvida por convicção e porque nenhuma das conclusões obrigava Portugal a modificar os seus regulamentos. Contudo, tal discrição também significa que, nesta questão, Portugal alinhava com a França e não apoiava as posições inglesas.

A pressão internacional - leia-se, inglesa - para a uniformização dos diversos regulamentos marítimos nacionais só veio, de facto, a fazer-se

${ }^{33}$ Relevé des conclusions adoptées para la Conférence en réponse aux questions de son programme. Constantinople: Imprimerie Centrale, 1866, p. 14-16.

${ }^{34}$ GOMES, Bernardino António - Aperçu..., cit., p. 16.

${ }^{35}$ Rapport sur les mesures à prendre en Orient pour prévenir de nouvelles invasions $d u$ choléra en Europe, Annexe au Procés-verbal n. ${ }^{\circ} 29$. Constantinople: Imprimerie Centrale, 1866, p. 15. 
sentir com maior força, em 1874, na III Conferência Sanitária Internacional, convocada para Viena, pelo governo austro-húngaro. Estiveram representados vinte e dois países. O assunto dominante foi, uma vez mais, a cólera. Portugal enviou o médico José Tomás de Sousa Martins, que tinha feito parte da comissão revisora do Regulamento Marítimo de Sanidade, publicado em 1860. Era intenção explícita no programa da Conferência identificar as diferenças nacionais, e trabalhar "até á total abolição" das medidas quarentenárias ${ }^{36}$.

Em Viena, se a transmissibilidade da doença não esteve em causa, as divergências foram substanciais no que tocava às medidas de combate consideradas eficazes. Se nas décadas anteriores ser "partidário (...) da índole contagiosa da enfermidade" significava ser "apologista das medidas quarentenárias”, em 1874, a Inglaterra, ainda que não recusasse tal teoria, continuava a pugnar por ver aligeiradas e uniformizadas as restrições impostas a passageiros e mercadorias.

Do ponto de vista científico, todos aceitaram a ideia de que a cólera era transmissível pelo homem; que este, vindo de uma origem infectada, podia ser o agente transmissor e que as mercadorias podiam ser veículo de contágio. A grande novidade é a unanimidade com que todos aceitaram que a moléstia podia ser propagada pela água. Os trabalhos epidemiológicos de John Snow, iniciados em Londres sob a vaga colérica de 1854, e correlacionando uma fonte infectada, os seus consumidores e as mortes por cólera, tinham, finalmente, dado os seus frutos ${ }^{37}$. A conclusão dos congressistas mais importante e mais inovadora consistiu na "negação da propagação pelo ar do gérmen causador da cólera"38; caíam, afinal, por terra as posições miasmáticas, base sobre a qual tinha assentado grande parte da oposição inglesa e germânica às quarentenas.

Dada a unanimidade das posições médicas acerca do contágio não deveria ter havido polémica. Mas, consoante se partia da ideia de contágio, ou da necessidade de evitar embaraços ao trânsito comercial chegava-se

${ }^{36}$ MARTINS, J. T. Sousa - Relatório dos trabalhos da Conferência Sanitária Internacional, reunida em Viena em 1874. Lisboa: Imprensa Nacional, 1874, p. 5.

37 JOHNSON, Steven - The Ghost Map. A Street, an epidemic and the two men who battled to save Victorian London. London: Allen Lane, 2006.

${ }^{38}$ MARTINS, J. T. Sousa - Relatório..., cit., p. 18. 
a resultados bem diversos. Uma conclusão em favor da abolição das quarentenas terrestres - que a Inglaterra e a Áustria julgavam poder fazer aprovar - encontrou a maior resistência. Contra a sua abolição pronunciaram-se Portugal, Grécia, Sérvia e França. Não que o delegado português as considerasse eficazes; mas entendia que cada país tinha o direito de impor as medidas sanitárias que melhor lhes conviesse. E este argumento de independência nacional, continuou a recolher as preferências de cada vez maior número de representantes, estendendo-se à questão das quarentenas marítimas: como se diz no relatório, "Pois quê? Propõem-nos as quarentenas para Suez e Alexandria e negam ao mesmo tempo que elas sejam eficazes na Europa?"39

O sistema de revisões, tal como proposto pela Inglaterra - inspeccionando do ponto de vista médico todas as pessoas a bordo, sequestrando em hospitais de isolamento os doentes ou suspeitos, permitindo a entrada livre, sem quarentena, a todos os outros depois de "beneficiação" - leia-se desinfecção-, "beneficiação" essa que se estenderia automaticamente a toda a carga parecia ao delegado português, como aos outros representantes dos países mediterrânicos, uma proposta utópica. Primeiro porque não havia acordo quanto ao desinfectante a utilizar, em seguida porque a ciência médica não sabia ainda como reconhecer a doença antes de os sintomas a terem revelado e, finalmente, ainda que Sousa Martins não o tivesse explicitado, porque isso implicaria uma administração sanitária que os países do Sul da Europa não tinham. Aos esforços de uniformização das medidas opôs-se, portanto, um bloco minoritário, inicialmente integrado por Portugal, Grécia e Sérvia, a que se juntaram o Egipto e a Turquia e, finalmente, a França e a Suíça.

A invocação do argumento climático acabou por convencer os congressistas: como escreveu Martins, "a influência do clima sobre a evolução das doenças e a influência do meio sobre a actividade social dos povos aliam-se de modo a permitirem que na carta geográfica se tracem as linhas divisórias (...) podendo dizer-se como lei quase geral que o rigor das medidas preventivas contra as doenças exóticas está na razão inversa da latitude" ${ }^{\sharp 0}$.

\footnotetext{
${ }^{39}$ Idem, p. 30

${ }^{40}$ Idem, p. 7.
} 
Em suma, e também devido aos esforços do médico português, liberalizaram-se as políticas. Optaram pela revisão a Alemanha, a Áustria-Hungria, a Bélgica, a Dinamarca, a Noruega, os Países Baixos, a Pérsia, a Rússia e a Suécia; e pelas quarentenas: o Egipto, a Grécia, a Espanha, a Roménia, a Turquia e Portugal. A Itália acabaria por aderir às quarentenas e lazaretos. A França optou pelas revisões para os seus portos do Norte, mas pelas quarentenas para os seus portos mediterrânicos e a Grã-Bretanha, tão desejosa de fazer abolir todas as restrições nos portos europeus, declarou-se pelas revisões nas ilhas britânicas, mas decidiu-se pela manutenção das quarentenas em Malta e Gibraltar.

Como se vê, a tradicional aliança entre Portugal e a Inglaterra não implicava a obediência cega aos ditames britânicos; e coube a Portugal o papel de fazer aceitar que aquilo que convinha ao comércio inglês significava "a ruína sanitária dos países meridionais" ${ }^{41}$, bem como convencer estes países, e até a França, da justeza da posição. Evidentemente, a própria Inglaterra não terá deixado de pesar na sua balança de interesses os riscos que corria o seu comércio se uma completa abolição das medidas fosse causa de uma nova epidemia.

\subsection{As Conferências depois da revolução bacteriológica}

Portugal não enviou representantes à Conferência Sanitária Internacional que se reuniu em Washington, em 1881. Mais diplomática do que científica, as potências representadas decidiram criar um sistema de informação epidémico internacional e estabelecer comissões internacionais de vigilância permanente em Alexandria. A ocupação britânica do Egipto, que ocorreria no ano seguinte, contudo, não só fez cessar a colaboração anglo-francesa nessa região, como se traduziu na liberalização da passagem dos navios ingleses. Não tardaram os protestos e as acusações de que a Inglaterra, em nome dos seus lucros comerciais, negligenciava a saúde pública europeia ${ }^{42}$.

\footnotetext{
${ }^{41}$ Idem, p. 39.

${ }^{42}$ BALDWIN, Peter - Contagion..., cit., p. 207.
} 
A Conferência reunida em Maio de 1885, em Roma, tinha por objectivo sanar estas divergências. Portugal far-se-á representar pelo seu embaixador em Roma, Matias de Carvalho e Vasconcelos e, como delegado técnico, por José Joaquim da Silva Amado, lente de Medicina Legal e Higiene Pública da Escola Médico-Cirúrgica de Lisboa ${ }^{43}$. Estiveram representados dezoito países e entre os delegados encontravam-se alguns dos mais eminentes médicos europeus: Koch pela Alemanha, Moleschott pela Itália e Brouardel pela França.

A Junta Consultiva de Saúde Pública formulou em 15 de Maio as instruções que Silva Amado deveria seguir: defender o princípio da liberdade nos regimes antiepidémicos nacionais, dado que no espaço europeu diferiam as condições topográficas, o clima e a importância das transacções comerciais e marítimas. Aquilo que a Junta Consultiva não acrescentou é que também diferiam os investimentos e as estruturas de vigilância e sanidade. Adicionalmente, recomendava-se que seria do interesse nacional que os representantes diplomáticos de Portugal em Alexandria tomassem assento no Conselho Sanitário permanente aí estabelecido ${ }^{44}$.

Recorde-se que, em 1885, a questão do contágio estava resolvida. Assim, dever-se-iam reexaminar as conclusões das Conferências precedentes e verificar a possibilidade de estabelecer um acordo internacional que, não descurando a saúde das populações, protegesse os interesses comerciais e a liberdade de navegação.

Uma vez mais serão as quarentenas marítimas o pomo da discórdia. Koch sublinhará que o contágio é interpessoal e que a organização de quarentenas e lazaretos teria de ter em conta a separação de doentes declarados e suspeitos. A Turquia mostrar-se-á inabalável na manutenção da sua política quarentenária, secundado pelo delegado português. O delegado inglês Thorne Thorne, por seu turno, não se cansará em defender uma política de saúde preventiva sustentada por inspecções sanitárias aos viajantes e

${ }^{43}$ AHD-MNE - Ofício do Ministério do Reino ao Ministério dos Negócios Estrangeiros de 8 de Maio de 1885. Conferências Sanitárias Internacionais, Roma, M 205.

${ }^{44}$ AHD-MNE - Instruções. Sessão de 15 de Maio da Junta Consultiva de Saúde Pública. Conferências Sanitárias Internacionais, Roma, M 205. 
seus contactos, após um desembarque sem demoras e a hospitalização de isolamento para os coléricos ${ }^{45}$.

Os delegados acabarão por chegar a um compromisso: nem a obrigatoriedade de repudiar as medidas quarentenárias nos portos europeus, nem a liberdade de trânsito dos navios no Canal do Suez. Mas, a duração das quarentenas impostas aos viajantes assintomáticos ficou reduzida. Apenas 5 dias de observação. E todos os navios vindos do Mar Índico cujos portos de origem estivessem infectados pela cólera (ou apenas suspeitos) seriam objecto de inspecção sanitária no canal de $\mathrm{Suez}^{46}$. O delegado inglês, naturalmente, votou contra.

Também se discutiu o sistema de informações internacionais. Recorde-se que em 1881 ficara acordada a obrigação de cada Estado informar acerca das epidemias que ocorressem no seu território. Agora (1885), a proposta de Silva Amado, que permitia aos representantes diplomáticos averiguar do estado sanitário dos portos por iniciativa própria, sem esperar por informação oficial, foi aprovada. Os conferencistas, contudo, recusaram a proposta americana que autorizaria os cônsules a visitar os navios, pessoalmente ou delegando num médico a inspecção, antes de passarem a respectiva carta de saúde. Tal seria, segundo os delegados, uma intolerável ingerência na autonomia nacional e inaceitável desconfiança das instituições locais. Contudo aprovar-se-á a proposta portuguesa, com os votos contra da Grã-Bretanha, Índia, Japão, Roménia, Sérvia e Turquia, no sentido de permitir que o cônsul do país de destino pudesse assistir às inspecções sanitárias feitas pelas autoridades locais ${ }^{47}$.

Em meados de Junho encerrou-se a Conferência. A expectativa era a de que os diversos governos viessem a celebrar um convénio. Em finais de Janeiro de 1886, as pressões diplomáticas avolumavam-se e a segunda parte da Conferência - de carácter político-diplomático - não parecia anunciar-se para breve. Em Portugal, o Ministro dos Negócios Estrangeiros, Barros

${ }^{45}$ Sessão de 25 de Maio de 1885 - Procés-Verbal $n{ }^{\circ} 3$. Conférence Sanitaire International, Rome, 1885 , p. 4-5.

${ }^{46}$ Sessão de 30 de Maio de 1885 - Procés-Verbal $n{ }^{\circ} 8$. Conférence Sanitaire International, Rome, 1885, p.10.

${ }^{47}$ Sessão de 27 de Maio de 1885 - Procés-Verbal $n{ }^{\circ}$ 5. Conférence Sanitaire International, Rome, 1885 , p. 3. 
Gomes, instava o seu colega da pasta do Reino para que se pronunciasse; este, por sua vez, invocava a demora do parecer pedido à Junta Consultiva de Saúde Pública. A Conferência de Roma acabou por não se traduzir em nenhum acordo europeu.

Em Dezembro de 1891, o Ministério dos Negócios Estrangeiros recebeu um convite formal para Portugal se fazer representar em Veneza onde, em Janeiro de 1892, se reuniria mais uma Conferência Sanitária Internacional. Portugal hesitou em se fazer representar, "atendendo a razões (...) ponderosas de severa economia nas despesas públicas" 48 . Mas, instado pelo governo austríaco, o Conde de Valbom, Ministro dos Negócios Estrangeiros, acabará por nomear o Conde de Macedo - ministro de Portugal em Roma-, como delegado português, com instruções para assinar ad referendum os protocolos finais.

O tema principal da Conferência será a reformulação do Conselho Sanitário do Egipto. Vários países europeus levantavam as mais sérias dúvidas sobre a sua actuação. Ora, como chamava a atenção o representante austríaco, secundado pelo delegado espanhol e francês, as novas doutrinas antiquarentenárias tinham-se traduzido por uma atitude excessivamente liberal. A proposta inglesa de não impor quarentenas aos navios destinados aos portos da Grã-Bretanha, independentemente do estado sanitário, parecia inadmissível. A Espanha queria que ficasse expresso que tais navios não poderiam fazer escala em nenhum porto do trajecto, sobretudo em Gibraltar, e a França não só invocava a igualdade de tratamento para todos os navios, como justificava a sua recusa por razões de defesa antiepidémica.

Nos bastidores, a França pressionava Portugal no sentido de se juntar ao bloco que se opunha à proposta inglesa, e os delegados franceses instavam o governo português a consultar Sousa Martins e Silva Amado, bem conhecidos dos franceses pela sua posição em favor da manutenção das quarentenas marítimas ${ }^{49}$. O Conde de Macedo receberá instruções para

${ }^{48}$ Ofício do Conde de Valbom ao Conde de Macedo, ministro de Portugal em Roma. 9 de Janeiro 1892 in Documentos apresentados às Cortes na sessão legislativa de 1893 pelo Ministro dos Negócios Estrangeiros. Secção IV. Convenção Sanitária Internacional de Veneza. Lisboa: Imprensa Nacional, 1893, p. 88.

${ }^{49}$ Telegrama confidencial do Conde de Macedo ao Conde de Valbom. 13 de Janeiro de 1892 in Documentos apresentados às Cortes..., cit., p. 90. 
"se concertar com os franceses e espanhóis" Portugal se reservava completa liberdade de acção com referência às medidas sanitárias que julgasse dever aplicar. Em Maio, o Ministério do Reino informava os Negócios Estrangeiros que não havia objecções à adesão de Portugal ao protocolo de Veneza, cuja redacção final incorporava as emendas francesas e as reservas portuguesas.

Em 1893, e apesar da Convenção de Veneza, as polémicas internacionais continuavam e uma nova Conferência reuniu-se em Dresden. A situação económica portuguesa continuava difícil e não se enviou delegado técnico à Conferência, mas tão-só o secretário da Legação de Berlim, Conde de Selir. Este deveria frisar que Portugal se reservava "de atender à defesa sanitária do reino como houver por mais conveniente" ${ }^{51}$, mas fazê-lo de modo a não suscitar antagonismos das potências, em particular da Alemanha (que como a Inglaterra desejava ver diminuídas as quarentenas marítimas), num momento "em que tanto precisamos do auxílio e benevolência do governo deste país para resolvermos a questão financeira" ${ }^{52}$. Tal como Portugal, muitos outros países (Dinamarca, Espanha, Grécia, Roménia, Sérvia, Suécia e Turquia) opuseram-se às medidas propostas pela Alemanha e Inglaterra e o protocolo final não obrigou a modificar as práticas nacionais.

Em 1897, reuniu-se novamente em Veneza uma Conferência Sanitária Internacional. Desta vez Portugal enviou como seu delegado técnico principal José Tomás Sousa Martins, a que se juntou o jovem Tomás de Mello Breyner. Mas este convénio - o último do século XIX - já não teve por assunto principal a cólera. Aquilo que nesse ano assustava os diversos governos europeus era a ameaça de peste bubónica, que tomara proporções assustadoras na Índia ${ }^{53}$ (e que em breve chegaria à Europa).

${ }^{50}$ Ofício de Artur Fevereiro da Direcção-Geral de Saúde a Eduardo Barreiros da DirecçãoGeral dos Negócios Consulares e Comerciais, em 23 de Janeiro de 1892 in Documentos apresentados às Cortes..., cit., p. 91.

${ }^{51}$ AHD-MNE - Ofício do Ministério do Reino ao Ministério dos Negócios Estrangeiros, Conferências Sanitárias Internacionais. Dresden, M 345 a M 363.

${ }^{52}$ AHD -MNE - Conferências Sanitárias Internacionais, Dresden, M 345 a M 363 (Conde de Selir, Ofício confidencial (aos Negócios Estrangeiros) em 22 de Fevereiro de 1893).

${ }^{53}$ Breyner, Tomás de Mello - Sousa Martins no Extrangeiro in Sousa Martins (In Memoriam). Lisboa: Casa da Moeda, 1904, p. 391. 


\section{Conclusão}

No século XX, a Europa não tornou a ser assolada por uma epidemia de cólera (ainda que outras se tenham traduzido por consequências devastadoras, com especial relevo para a de gripe, em 1918). Em Portugal, a peste bubónica grassou no Porto, em 1899 e a cólera devastou a ilha da Madeira em 1910-11. Quer numa quer noutra ocasião Ricardo Jorge dirigiu o combate antiepidémico: na primeira, mais de perto, como delegado de saúde do Porto e responsável pelo Laboratório Bacteriológico Municipal daquela cidade e, na segunda, enquanto director-geral de saúde. A estratégia adoptada no Porto, em 1899, e que será seguida em todas as epidemias infecto-contagiosas posteriores (quer a de cólera da Madeira, quer as de tifo exantemático ou ainda a de gripe) é semelhante à adoptada por outros países em circunstâncias semelhantes, pelo que se poderia sustentar que, apesar das resistências demonstradas ao longo do século XIX, chegara-se a um consenso internacional. A divisão do espaço em circunscrições médico-farmacêuticas, a vigilância médica e policial das populações, a desinfecção de habitações, bens e roupas, a hospitalização de isolamento para os contaminados evitará a quarentena indiscriminada e tornará inúteis os cordões sanitários fronteiriços (ainda que a restrição pudesse ser determinada a uma casa, rua, bairro ou cidade). Da mesma forma, à chegada dos navios, a hospitalização de doentes declarados e o desembarque livre de passageiros assintomáticos (após exame bacteriológico) - que ficavam contudo sujeitos a inspecções durante o período possível de incubação da doença - foram as práticas adoptadas também em Portugal.

A uniformização das medidas tornou-se mais fácil isolado o agente causador da cólera e com a compreensão dos processos de contágio. Deixara de haver contradição entre teorias contagionistas e práticas higienistas. As novas teorias do contágio exigiam o saneamento das cidades e a higiene individual. E aceites estes pressupostos, o Estado e a opinião pública foram sendo convencidos da necessidade de despender mais meios na defesa da saúde pública com carácter permanente. A Lei de 17 de Agosto de 1899 e o Regulamento Geral de Saúde e Beneficência Pública, de 1901, são já o resultado de uma nova atitude dos poderes públicos para com a saúde das populações. 
Finalmente, o olhar retrospectivo permite mostrar como, em matéria sanitária - e em particular no caso da cólera -, as posições de Portugal dependiam da opinião dos especialistas, da posição geográfica do país na marcha das epidemias, do estado epidémico da, e das medidas adoptadas pela sua vizinha Espanha, das força ou fraqueza das suas trocas comerciais, como, sobretudo, ilustram a influência recíproca entre medicina e política. Quer os defensores das teorias miasmáticas - preponderantes entre 1850 e 1880 - quer os advogados das teorias do contágio, após a descoberta de Koch, foram insistindo na necessidade de maior intervencionismo estatal. O Estado, por sua vez, foi tutelando o poder dos médicos, vigiando a sua profissionalização e regulamentando os seus procedimentos, sobretudo quando e se os incorporava na máquina burocrática estatal. 